\title{
PENGARUH PEMBERDAYAAN, MOTIVASI DAN LINGKUNGAN KERJA TERHADAP PRODUKTIVITAS KERJA KARYAWAN
}

\author{
Ni Made Ita Purnami ${ }^{1}$ \\ I Wayan Mudiartha Utama ${ }^{2}$ \\ ${ }^{1,2}$ Fakultas Ekonomi dan Bisnis Universitas Udayana (Unud), Bali, Indonesia \\ email: itapurnami22@gmail.com
}

\begin{abstract}
ABSTRAK
Tujuan dari penelitian ini adalah untuk mengetahui pengaruh pemberdayaan, motivasi dan lingkungan kerja terhadap produktivitas kerja karyawan. Penelitian ini dilakukan di Legong Keraton Beach Hotel. Jumlah responden yang diteliti sebanyak 41 orang karyawan, dengan menggunakan sampel jenuh. Pengumpulan data dilakukan melalui wawancara dan menyebar kuesioner. Teknik analisis yang digunakan adalah regresi linier berganda. Penemuan dalam penelitian ini adalah pemberdayaan, motivasi dan lingkungan kerja berpengaruh positif dan signifikan terhadap produktivitas kerja karyawan. Legong Keraton Beach Hotel diharapkan lebih memperhatikan karyawan, memberikan kesempatan kepada karyawan untuk membuat keputusan, memberikan dukungan dan motivasi, memberikan gaji sesuai dengan beban kerja karyawan, menjaga kebersihan lingkungan serta menjaga hubungan yang baik didalam perusahaan sehingga akan mempengaruhi produktivitas kerja untuk mencapai tujuan dengan efektif dan efisien.
\end{abstract}

Kata kunci : pemberdayaan, motivasi, lingkungan kerja, produktivitas kerja karyawan

\begin{abstract}
The purpose of this study is to find out the effect of empowerment, motivation and work environment on employee work productivity. This research was conducted at Legong Keraton Beach Hotel. The number of respondents studied was 41 employees, using saturated samples. Data collection is done through interviews and questionnaires. The analysis technique used is multiple linear regression. The findings in this study were that empowerment, motivation and work environment had a positive and significant effect on employee work productivity. Legong Keraton Beach Hotel is expected to pay more attention to employees, provide opportunities for employees to make decisions, provide support and motivation, provide salaries according to the workload of employees, maintain cleanliness of the environment and maintain good relationships within the company so that it will affect work productivity to achieve goals effectively and efficient.

Keywords: empowerment, motivation, work environment, work productivity of employees
\end{abstract}




\section{PENDAHULUAN}

Bali merupakan salah satu destinasi wisata yang ada di dunia. Perpaduan budaya dan keindahan alam menjadikan Bali sebagai tujuan pariwisata, baik bagi wisatawan domestik maupun mancanegara. Pariwisata Bali sudah berkembang dengan sangat pesat, sehingga memberikan sumbangan yang besar terhadap pembangunan daerah dan menciptakan kesejahteraan masyarakat Bali.

Salah satu cara untuk meningkatkan jumlah wisatawan yang berkunjung ke Bali adalah dengan memberikan pelayanan jasa yang memuaskan untuk wisatawan yang berlibur ke Bali, yang nantinya diharapkan wisatawan tersebut dapat memberikan informasi yang baik kepada teman-teman maupun keluarga mengenai Bali sekaligus dapat mempromosikan Bali di negaranya.

Perkembangan sektor pariwisata di Bali menyebabkan banyak dibangun tempat penginapan seperti villa maupun hotel. Banyaknya tempat penginapan yang dibangun di Bali menyebabkan persaingan dalam dunia usaha dan bisnis hotel sangat ketat. Menghadapi persaingan yang semakin ketat, Sumber Daya Manusia (SDM) dituntut untuk terus mengembangkan diri dan meningkatkan kemampuan serta skill yang dimiliki, agar perusahaan mampu bertahan dalam persaingan yang terjadi.

Ardana et al. (2014:3) menyatakan manusia merupakan harta yang sangat berharga dan memiliki peran yang paling penting dalam suatu organisasi/perusahaan, karena keberhasilan organisasi sangat ditentukan oleh unsur manusia.

Produktivitas kerja karyawan menjadi hal yang penting bagi perusahaan/organisasi untuk mencapai tujuan. Setiap bisnis yang sukses sebagian besar keberhasilannya karena karyawan yang rajin dengan produktivitas yang sangat baik (Itumbiri, 2013).

Hanaysha (2016) menyebutkan produktivitas kerja adalah faktor penting di dalam perusahaan untuk membangun organisasi yang memiliki daya saing, mencapai tujuan perusahaan, memiliki kinerja yang baik serta memenuhi proporsi dalam memangku kepentingan organisasi. Produktivitas kerja karyawan adalah perbandingan antara hasil yang dicapai dengan peran serta tenaga kerja (Ardana et al., 2014:270).

Menurut Hamali (2013) keberhasilan dalam perusahaan merupakan faktor utama yang selalu ingin dicapai, dalam keberhasilan tersebut terdapat SDM yang memiliki peran penting, dimana produktivitas kerja merupakan suatu keunggulan yang kompetitif bagi perusahaan.

Produktivitas kerja karyawan yang tinggi dapat diperoleh apabila karyawan memiliki keinginan untuk meningkatkan kemampuan yang dimiliki, sehingga tujuan perusahaan akan terlaksana secara efektif dan efisien.

Huzain (2015) menyatakan bahwa karyawan akan lebih baik dan giat serta lebih disiplin dalam segala hal termasuk karyawan semakin jujur dan loyal terhadap perusahaan yang pemimpin terus memberikan motivasi karyawannya. Menurut Kien (2012) produktivitas kerja yang meningkat dapat memberikan keuntungan seperti keunggulan kompetitif, mempertahankan hasil strategis, mencapai tujuan organisasi dan memenuhi nilai proporsi stakkeholder. 
Hanaysha (2016) menyatakan bahwa meningkatkan produktivitas kerja karyawan merupakan salah satu tujuan dari perusahaan untuk dapat melihat produktif atau tidaknya suatu perusahaan. Dengan adanya produktivitas kerja yang tinggi, dapat menggambarkan tingkat keefektifan dan keefisienan kerja karyawan dalam suatu perusahaan.

Produktivitas kerja karyawan dapat dipengaruhi oleh beberapa faktor yaitu tingkat pendidikan, pelatihan, keterampilan, disiplin, sikap, etika kerja, motivasi, lingkungan kerja, sarana produksi dan kesehatan (Sutrisno, 2009:102). Oleh sebab itu, produktivitas kerja karyawan menjadi hal yang sangat penting dan harus diperhatikan. Rendahnya produktivitas kerja karyawan terletak dari moral kerja yang rendah, para karyawan selalu memanfaatkan waktu kerja dengan pekerjaan yang tidak sesuai dengan sasaran organisasi akibatnya banyak dari karyawan bermalas-malasan atau bahkan korupsi jam kerja (Swandono, 2016).

Legong Keraton Beach Hotel merupakan perusahaan yang bergerak dalam bidang jasa penginapan yang beralamat di Jl. Pantai Berawa, Tibubeneng, Kuta Utara, Badung, Bali. Jumlah kamar yang tersedia sebanyak 40 kamar dan jumlah karyawan sebanyak 43 orang.

Untuk mancapai target yang sudah ditetapkan oleh perusahaan, karyawan melakukan promosi di media sosial dan berusaha meningkatkan kualitas pelayanan yang diberikan. Untuk memberikan kualitas pelayanan yang memuaskan, maka perusahaan perlu meningkatkan produktivitas kerja karyawannya.

Berdasarkan hasil wawancara yang dilakukan terhadap manajer, bahwa masih ada karyawan di Legong Keraton Beach Hotel yang belum bekerja dengan optimal dan produktif dalam melakukan pekerjaan. Hal tersebut dapat dilihat dengan adanya komplin dari pelanggan terhadap pelayanan yang diberikan oleh karyawan Legong Keraton Beach Hotel.

Rata-rata komplin dari pelanggan 10-15 kali setiap bulannya, seperti komplin tentang keterlambatan pelayanan yang diberikan, permintaan dari pelanggan yang lama dijalankan, komplin masalah kebersihan, karyawan yang tidak sopan, rasa makanan yang tidak sesuai, maka dapat diindikasikan bahwa produktivitas kerja karyawan masih rendah. Indikasi rendahnya produktivitas kerja karyawan juga dapat dilihat dari jumlah hunian di Legong Keraton Beach Hotel per bulannya yang cenderung menurun.

Data pada Tabel 1. menunjukan bahwa produktivitas kerja karyawan masih rendah, dimana tingkat hunian di Legong Keraton Beach Hotel cenderung menurun. Hal tersebut ditunjukan pada bulan Januari sampai Mei 2017 hunian di Legong Keraton Beach Hotel menurun. Bulan Juni sampai Agustus mengalami peningkatan dan pada bulan September sampai April 2018 kembali mengalami penurunan. Pada bulan Mei sampai Agustus 2018 kembali meningkat.

Peningkatan jumlah hunian pada tahun 2017 belum mencapai target yang ditetapkan, tetapi peningkatan jumlah hunian pada Agustus 2018 sudah mencapai target. Semakin sedikit jumlah hunian maka produktivitas kerja karyawan dapat diindikasikan rendah. Hasil wawancara terhadap 5 orang karyawan di Legong Keraton Beach Hotel menunjukan permasalahan seperti karyawan kurang diberdayaan, kurangnya motivasi yang dimiliki oleh karyawan dan lingkungan kerja yang kurang nyaman. 
Berikut Tabel 1. jumlah hunian di Legong Keraton Beach Hotel.

Tabel 1.

Jumlah Hunian di Legong Keraton Beach Hotel Tahun 2017 dan 2018

\begin{tabular}{clccc}
\hline \multirow{2}{*}{2017} & Periode & $\begin{array}{c}\text { Target Hunian } \\
\text { per Bulan } \\
\text { (kamar) }\end{array}$ & $\begin{array}{c}\text { Jumlah Hunian } \\
\text { per Bulan } \\
\text { (kamar) }\end{array}$ & Capaian (\%) \\
\hline Tahun & Januari & 1240 & 924 & 75 \\
& Februari & 1120 & 780 & 70 \\
& Maret & 1240 & 803 & 65 \\
& April & 1200 & 760 & 64 \\
& Mei & 1240 & 729 & 59 \\
Juni & 1200 & 958 & 80 \\
Tahun & Juli & 1240 & 1200 & 97 \\
& Agustus & 1240 & 1215 & 93 \\
& September & 1200 & 1118 & 89 \\
& Oktober & 1240 & 1101 & 65 \\
& November & 1200 & 860 & 65 \\
& Desember & 1240 & 800 & 64 \\
& Januari & $\mathbf{1 4 6 0 0}$ & $\mathbf{1 1 2 4 8}$ & 63 \\
& Februari & 1240 & 800 & 63 \\
& Maret & 1120 & 715 & 61 \\
& April & 1240 & 778 & 76 \\
& Mei & 1200 & 760 & 95 \\
& Juni & 1240 & 754 & 100 \\
& Juli & 1200 & 913 & \\
& Agustus & 1240 & 1172 & $\mathbf{7 1 3 2}$ \\
\hline
\end{tabular}

Sumber: Legong Keraton Beach Hotel, 2018

Indikasi kurangnya pemberdayaan, ketika diberikan pekerjaan karyawan merasa tidak bisa menyelesaikan pekerjaan sesuai apa yang diharapkan dan karyawan tidak memiliki kebebasan dalam menyelesaikan pekerjaan yang diberikan. Jika ada pelanggan yang komplin terhadap pelayanan yang diberikan, karyawan tidak bisa memutuskan hal apa yang harus dilakukan. Karyawan tersebut hanya menunggu arahan dari atasan dan kurang inisiatif.

Pemberdayaan karyawan merupakan strategi penting bagi organisasi untuk meningkatkan kekuatan dan keterlibatan karyawan mereka dengan asumsi bahwa karyawan yang diberdayakan cenderung lebih efisien dalam menyelesaikan pekerjaan mereka (Prabawa \& Supartha, 2018). Terkait dengan penelitian sebelumnya bahwa variabel pemberdayaan memberikan pengaruh yang kuat terhadap produktivitas, berarti ada kaitan antara variabel pemberdayaan dengan produktivitas (Arifin et al., 2014).

Penelitian yang dilakukan Hamali (2013) menunjukkan bahwa motivasi berpengaruh terhadap produktivitas kerja karyawan. Motivasi adalah hal yang harus dimiliki oleh setiap karyawan dalam melakukan pekerjaan agar bersemangat dalam bekerja. Indikasi kurangnya motivasi karyawan dalam bekerja, seperti karyawan tidak berani bertanggung jawab dalam menyelesaikan pekerjaan di luar bidang pekerjaan yang digeluti. Rendahnya motivasi karyawan Legong Keraton Beach 
Hotel, ditunjukan dalam melakukan pekerjaan, karyawan tidak memberikan pelayanan maksimal kepada pelanggan. Terbukti dengan adanya komplin dari pelanggan kepada Hotel.

Produktivitas merupakan kemampuan karyawan mencapai tugas tertentu sesuai dengan standar, kelengkapan, biaya, dan kecepatan sehingga pemanfaatan SDM yang efisien dan efektif dalam suatu organisasi (Hanaysha, 2016). Produktivitas kerja merupakan tantangan penting dalam organisasi terutama dalam mengelola SDM. Keberhasilan organisasi tergantung pada produktivitas kerja karyawan. Perusahaan pasti menginginkan karyawan yang memiliki produktivitas kerja yang tinggi dalam bekerja.

Produktivitas karyawan adalah hal penting yang harus diberikan perhatian, karena tujuan utama dalam melakukan pekerjaan adalah untuk mendapatkan output maksimum dengan biaya minimum. (Ardana et al., 2014:271) menyatakan bahwa dilihat dari sudut philosofis produktivitas adalah suatu sikap yang mempunyai pandangan bahwa mutu kehidupan hari ini lebih baik dari kemarin dan besok harus lebih baik dari hari ini, dilihat dari sudut teknis produktivitas adalah perbandingan antara hasil yang dicapai (output) dengan keseluruhan sumber daya yang digunakan, sedangkan dari sudut ukuran tingkat efisiensi dan efektivitas dilihat dari sumber daya yang digunakan selama produksi berlangsung. Karyawan yang produktif memiliki kemampuan dalam bekerja, baik dari keahlian maupun keterampilan yang dimiliki.

Produktivitas sebagai kemampuan untuk mencapai tugas-tugas tertentu sesuai dengan standar yang telah ditentukan atau ditetapkan (Ahmed et al., 2012). Menurut Kien (2012) produktivitas kerja yang meningkat dapat memberikan keuntungan seperti keunggulan kompetitif, mempertahankan hasil strategis, mencapai tujuan organisasi dan memenuhi nilai proporsi stakkeholder.

Hanaysha (2016) menyatakan bahwa produktivitas kerja karyawan dapat dilihat berdasarkan kuantitas dan kualitas kerja yang dilakukan oleh karyawan dengan mempertimbangkan biaya sumber daya yang digunakan untuk mencapai pekerjaan. Ferreira dan Plessis (2009) mengatakan bahwa produktivitas adalah waktu yang dihabiskan oleh seorang karyawan dalam melaksanakan tugas atau pekerjaan dalam rangka mencapai hasil yang diharapkan berdasarkan deskripsi pekerjaan.

Menurut (Ardana et al., 2014:271) produktivitas kerja karyawan adalah perbandingan antara hasil kerja yang dicapai dengan peran serta tenaga kerja dalam satuan waktu. Jadi produktivitas kerja karyawan adalah kemampuan untuk meningkatkan hasil kerja dan mencapai tugas-tugas tertentu sesuai dengan standar yang ditetapkan. Meningkatnya produktivitas disebabkan karena meningkatnya efisiensi (waktu, bahan, tenaga) dan sistem kerja, teknis produksi dan adanya peningkatan keterampilan dari karyawan (Salistera \& Kusumastuti, 2013). Oleh sebab itu, manajer SDM harus mampu membuat strategi untuk meningkatkan produktivitas kerja karyawan.

Memberikan pemberdayaan terhadap karyawan bertujuan untuk mengaktifkan karyawan untuk membuat keputusan yang diperlukan dan menanggapi setiap perubahan yang mungkin timbul dalam lingkungan bisnis setiap saat. Elnaga dan Imran (2014) menyatakan pemberdayaan karyawan dibangun 
dengan merancang lingkungan kerja dimana karyawan diizinkan untuk membuat keputusan berdasarkan pekerjaan yang berhubungan dengan kondisi tertentu.

Chen (2011) menyatakan bahwa pemberdayaan adalah tentang karyawan yang menjalankan kebijaksanaan, otonomi, kekuasaan dan kontrol dalam pekerjaan mereka untuk memberikan kinerja yang diharapkan. Pemberdayaan adalah kumpulan dari sistem, metode dan tindakan untuk mengembangkan kemampuan dan kompetensi individu untuk meningkatkan produktivitas, pengembangan organisasi, pertumbuhan, kemakmuran dan sumber daya manusia (Asgarsani et al., 2013) .

Dalam menghadapi permasalahan yang semakin rumit, para manajer maupun atasan sangat memerlukan bantuan dari karyawannya. Semakin karyawan itu mampu dan berani menghadapi masalah maka semakin efisien dan efektif kegiatan dalam perusahaan. Banyak pemimpin yang kurang atau bahkan tidak percaya terhadap karyawannya untuk menghadapi suatu masalah. Maka dari itu pemimpin seharusnya memberi wewenang, tanggung jawab dan kepercayaan terhadap karyawan.

Meyerson dan Dewettinck (2012) mengatakan bahwa pemberdayaan adalah proses menstransfer kekuasaan, otoritas dengan tanggung jawab dan akuntabilitas kepada karyawan melalui manajer. Sedangkan Jacquiline (2014) mengatakan dengan adanya pemberdayaan, karyawan akan mengembangkan kompetensi yang dimiliki untuk melakukan tugas dengan menerapkan pengetahuan dan keterampilan. Keuntungan dari pemberdayaan karyawan meliputi peningkatan tanggung jawab, semangat kerja karyawan yang tinggi, dan kualitas hidup yang lebih baik dalam bekerja (Prabawa \& Supartha, 2018). Jadi pemberdayaan adalah kebebasan yang diberikan oleh pihak manajemen terhadap karyawan untuk memiliki rasa tanggung jawab, wewenang dalam melaksanakan pekerja dengan memberikan kepercayaan terhadap karyawan.

Lea dan Wibawa (2014) dalam penelitiannya menyebutkan bahwa lingkungan kerja merupakan salah satu tempat dimana pekerja menghabiskan sebagian waktu mereka dalam menyelesaikan pekerjaannya dan beristirahat sejenak dari aktivitas bekerja. Lingkungan kerja merupakan komponen-komponen yang berhubungan dengan suatu lembaga, organisasi atau perusahaan yang memiliki suatu pola yang tidak lepas dari lingkungan dimana lembaga, organisasi, atau perusahaan itu berada. Lingkungan kerja secara langsung maupun tidak langsung akan memiliki dampak bagi perusahaan dan berpengaruh pada kinerja dari karyawan perusahaan. Lingkungan kerja yang nyaman dapat meningkatkan produktivitas kerja karyawan, sehingga menimbulkan perasaan nyaman dalam diri karyawan. Karyawan merasa lebih termotivasi dan semangat dalam bekerja, karena karyawan memiliki hubungan yang baik dengan atasan atau dengan sesama rekan kerja.

Subagyo (2014) menyatakan lingkungan kerja adalah komponen dari dalam dan luar organisasi yang dapat mempengaruhi kinerja organisasi. Lingkungan kerja merupakan komponen yang dapat dikendalikan dan juga tidak dapat dikendalikan dalam keadaan tertentu. Lingkungan kerja merupakan kondisi yang ada di tempat kerja baik itu fisik maupun non fisik yang mempengaruhi pegawai dalam menjalankan pekerjaannya. 
Menurut Ahyari (2011:124) lingkungan kerja yaitu suatu kondisi dimana karyawan melaksanakan dan menjalankan tugas dan pekerjaannya setiap harinya. Menurut Senata et al. (2014) manfaat lingkungan kerja adalah menciptakan gairah kerja sehingga produktivitas kerja meningkat.

Kondisi lingkungan kerja yang baik dan sehat dalam organisasi juga akan mendorong karyawan agar lebih termotivasi untuk mengerahkan segala kemampuannya dalam mengerjakan tugas yang diberikan serta tidak menyimpang dari tujuan atau misi awal perusahaan (Bachtiar, 2012).

Lingkungan kerja yang kondusif dan nyaman akan mempengaruhi semangat kerja karyawan sehingga karyawan termotivasi untuk mencapai tujuan perusahaan(Swandono, 2016). Jadi lingkungan kerja adalah segala sesuatu yang ada disekitar karyawan yang dapat mempengaruhi kinerja karyawan dalam melaksanakan pekerjaannya sehingga memperoleh hasil yang maksimal.

Lingkungan kerja merupakan kondisi yang ada di tempat kerja baik itu fisik maupun non fisik yang mempengaruhi karyawan dalam menjalankan pekerjaannya (Subagyo, 2014). Kondisi dan fasilitas di lingkungan kerja yang sesuai dengan harapan karyawan dapat meningkatkan produktivitas kerja terhadap pekerjaan yang mereka miliki dan perusahan tempat mereka bekerja (Maslichah \& Hidayat, 2017).

Lingkungan kerja yang baik memiliki peranan penting dalam meningkatkan produktivitas kerja karyawan dalam perusahaan (Swandono, 2016). Lingkungan kerja yang baik dapat dilihat dari suasana kerja seperti penerangan yang cukup, sirkulasi udara yang baik, tersedianya alat-alat pengamanan, hubungan karyawan yang baik, dan fasilitas yang diberikan.

Senata et al. (2014) menyatakan bahwa Lingkungan kerja berpengaruh positif terhadap produktivitas kerja karyawan. Indikasi kurangnya kenyamanan karyawan dengan lingkungan kerjanya, dimana karyawan belum merasa nyaman seperti saling iri, saling tunggu dengan teman pada saat bekerja.

Pemberdayaan dikatakan memberikan kontribusi bagi keberhasilan suatu organisasi. Chang dan Liu (2007) mengatakan bahwa pemberdayaan merupakan faktor penting dalam meningkatkan produktivitas. Chehrazi dan Shafizadeh (2016) menyatakan bahwa terdapat hubungan yang erat antara pemberdayaan karyawan dengan kepuasan kerja, sehingga dapat meningkatkan produktivitas.

Menurut Hanaysha (2016) pemberdayaan karyawan telah secara luas diakui sebagai kontributor kunci keberhasilan organisasi, dan banyak yang meneliti hubungan langsung antara tingkat pemberdayaan karyawan dan produktivitas kerja. Pemberdayaan memberikan pengaruh yang kuat terhadap produktivitas (Arifin et al., 2014). Pemberdayaan memiliki pengaruh positif dan signifikan terhadap produktivitas karyawan (Prabawa \& Supartha, 2018). Berdasarkan penelitian sebelumnya, maka dapat disusun hipotesis sebagai berikut:

$\mathrm{H}_{1}$ : Pemberdayaan berpengaruh positif dan signifikan terhadap produktivitas kerja karyawan

Penelitian yang dilakukan oleh Hamali (2013) menunjukan bahwa motivasi berpengaruh positif terhadap produktivitas karyawan. Secara keseluruhan motivasi karyawan cukup baik. Akan tetapi, dimensi motivasi ekstrinsik memiliki nilai bobot 
di bawah rata-rata variabel motivasi, yaitu pada indikator keterlibatan karyawan di perusahaan. Motivasi mempunyai pengaruh positif dan signifikan terhadap produktivitas kerja karyawan. Pengaruh yang positif ini menunjukkan bahwa semakin baik persepsi responden mengenai dorongan motivasi pegawai telah berhasil meningkatkan produktivitas kerja (Purwanto \& Wulandari, 2016).

Omollo (2015) juga menilai bahwa motivasi berpengaruh positif terhadap produktivitas kerja karyawan jika imbalan yang diterima sesuai dengan apa yang menjadi beban pekerjaan karyawan itu. Maduka dan Okafor (2014) mengatakan bahwa motivasi menjadi hal yang sangat berpengaruh dan penting dalam meningkatkan produktivias dari organisasi.

Nuraini et al. (2015) juga mengatakan bahwa motivasi berpengaruh secara parsial terhadap produktivitas kerja karyawan. Dengan demikian semakin baik motivasi dan lingkungan kerja di perusahaan tersebut maka produktivitas kerja karyawan juga akan semakin baik. Berdasarkan penelitian sebelumnya, maka dapat disusun hipotesis sebagai berikut:

$\mathrm{H}_{2}$ : Motivasi berpengaruh positif dan signifikan terhadap produktivitas kerja karyawan

Penelitian yang dilakukan oleh Penelitian yang dilakukan oleh Nuraini et al., (2015) menyimpulkan bahwa motivasi dan lingkungan kerja berpengaruh positif terhadap produktivitas karyawan. Lingkungan kerja berpengaruh positif terhadap produktivitas kerja karyawan bagian produksi minyak kelapa sawit PT. Mitra (Swandono, 2016). Penelitian yang dilakukan oleh Taiwo (2010) menyatakan bahwa lingkungan kerja dapat meningkatkan produktivitas kerja karyawan karena lingkungan kerja yang kondusif.

Penelitian yang dilakukan oleh Senata et al. (2014) menyatakan bahwa Lingkungan kerja berpengaruh positif terhadap produktivitas kerja karyawan. Menurut Ajala (2012) Lingkungan tempat kerja yang kondusif yang membantu kinerja kerja secara otomatis meningkatkan produktivitas. Berdasarkan penelitian sebelumnya , maka dapat disusun hipotesis sebagai berikut:

$\mathrm{H}_{3}$ : Lingkungan kerja berpengaruh positif dan signifikan terhadap produktivitas kerja karyawan.

\section{METODE PENELITIAN}

Lokasi pada penelitian ini dilakukan di Legong Keraton Beach Hotel, yang beralamat di Jl. Pantai Berawa, Tibubeneng, Kuta Utara, Badung, Bali. Populasi dalam penelitian ini adalah seluruh karyawan Legong Keraton Beach Hotel yang berjumlah 43 orang. Pada penelitian ini seluruh karyawan dalam populasi berjumlah 43 orang, tetapi 1 orang general manager dan 1 orang HRD tidak disertakan dalam pengambilan data karena dalam pernyataan kuesioner ada pernyataan mengenai sikap atasan. Metode penentuan sampel dalam penelitian ini termasuk dalam penelitian populasi (sampel jenuh). Penelitian populasi dipilih karena jumlah responden yang diteliti kurang dari 100 orang. 
Berikut adalah data jumlah karyawan di Legong Keraton Beach Hotel pada Tabel 2.

Tabel 2.

Data Jumlah Karyawan di Legong Keraton Beach Hotel

\begin{tabular}{clc}
\hline No. & \multicolumn{1}{c}{ Jabatan } & Jumlah \\
\hline 1 & General Manager & 1 \\
2 & Manager Operational/HRD & 1 \\
3 & Marketing & 1 \\
4 & Spv. HK, Maintanance, Engineering, Gardener & 1 \\
5 & Spv.F.B / Purchasing & 1 \\
6 & Coordinator Security & 1 \\
7 & Accounting & 1 \\
8 & Spv. FO and Spa & 1 \\
9 & Housekeeping & 6 \\
10 & Maintanance \& Engineering & 2 \\
11 & Gardener & 2 \\
12 & Cook/Bartender & 6 \\
13 & Service (waiter/waitress) & 6 \\
14 & Purchasing & 1 \\
15 & Security & 4 \\
16 & Cashier & 1 \\
17 & Tax & 1 \\
18 & Spa & 1 \\
19 & Front Office & 5 \\
& Total & 43 \\
\hline
\end{tabular}

Sumber: Legong Keraton Beach Hotel, 2018

Produktivitas kerja karyawan adalah kemampuan untuk meningkatkan hasil kerja dan mencapai tugas-tugas tertentu sesuai dengan standar yang ditetapkan. Indikator-indikator produktivitas karyawan adalah 1) Kemampuan ( $\left.\mathrm{Y}_{1}\right)$, indikator ini diukur melalui kemampuan karyawan bekerja secara profesional dan kemampuan karyawan untuk menyelesaikan tugas-tugas dalam bekerja dengan tepat waktu. 2) Meningkatkan hasil yang dicapai ( $\left.\mathrm{Y}_{2}\right)$, Indikator yang diukur dari persepsi karyawan untuk selalu meningkatkan hasil yang dicapai dalam bekerja dibandingkan dengan hasil sebelumnya dan mampu menyelesaikan permasalahan dalam bekerja. 3) Semangat Kerja $\left(\mathrm{Y}_{3}\right)$, semangat kerja berkaitan dengan kesungguhan seorang karyawan mengerjakan pekerjaannya. Indikator ini diukur dari persepsi karyawan semangat dalam bekerja. 4) Pengembangan Diri ( $\left.\mathrm{Y}_{4}\right)$, Pengembangan diri berkaitan dengan peningkatan kualitas diri. Indikator ini diukur dari persepsi karyawan untuk meningkatkan kemampuan bekerja dan karyawan selalu intropeksi diri terhadap kesalahan dalam bekerja. 5) Mutu ( $\mathrm{Y}_{5}$ ), indikator yang diukur dari persepsi karyawan terhadap hasil kerja yang memenuhi standar mutu yang telah ditentukan perusahaan. Indikator ini diukur dengan persepsi karyawan untuki memenuhi standar mutu dari perusahaan. 6) Efisiensi ( $\left.\mathrm{Y}_{6}\right)$, efisiensi berkaitan dengan hasil yang dicapai keseluruhan sumber daya yang digunakan. Indikator ini diukur dari persepsi karyawan dalam menyelesaikan pekerjaan secara efisien sesuai dengan standar kerjanya.

Pemberdayaan adalah kebebasan yang diberikan oleh pihak manajemen terhadap karyawan untuk memiliki rasa tanggung jawab, wewenang dalam 
melaksanakan pekerja dengan memberikan kepercayaan terhadap karyawan Adapun indikator pemberdayaan adalah 1) Keterlibatan $\left(\mathrm{X}_{1,1}\right)$, keterlibatan merupakan tahap pertama dalam model pemberdayaan dengan adanya keterlibatan karyawan dalam menyelesaikan pekerjaan. Hal tersebut dapat dicapai melalui pemberian kesempatan untuk mengidentifikasikan permasalahan, mendorong terciptanya perspektif baru serta melatih karyawan untuk mengawasi dirinya sendiri. Indikator ini diukur melalui keterlibatan karyawan dalam menyelesaikan pekerjaan yang diberikan. 2) Kepercayaan $\left(X_{1,2}\right)$, kepecayaan dari pihak manajemen terhadap karyawan adalah hal yang penting dalam perusahaan. Adanya rasa saling percaya tersebut akan menciptakan kondisi yang baik untuk pertukaran informasi dalam bekerja. Indikator ini dapat diukur melalui hubungan karyawan dengan manajemen dan rekan kerja. 3) Kepercayaan diri $\left(\mathrm{X}_{1,3}\right)$, kepercayaan diri merupakan hal yang harus dimiliki oleh karyawan. Kepercayaan diri ini dapat menimbulkan rasa saling percaya dan menghargai kemampuan yang dimiliki oleh karyawan. Indikator ini dapat diukur melalui rasa percaya diri yang dimiliki karyawan dalam melaksanakan pekerjaan yang diberikan. 4) Kredibilitas $\left(\mathrm{X}_{1,4}\right)$, kredibilitas berkaitan dengan penghargaan dan pengembangan lingkungan kerja yang mampu mendorong kompetisi yang sehat sehingga dapat meningkatkan produktivitas kerja karyawan. Indikator ini dapat diukur melalui kebebasan karyawan untuk membuat keputusan dalam melaksanakan pekerjaan. 5) Akuntabilitas $\left(\mathrm{X}_{1,5}\right)$, kewajiban dan pertanggung jawaban pada wewenang yang diberikan dengan tujuan untuk mendapatkan secara konsisten dan jelas tentang peran, standar, dan tujuan dalam penilaian kinerja karyawan. Indikator ini dapat diukur melalui kepercayaan yang diberikan atasan terhadap karyawan. 6) Komunikasi $\left(\mathrm{X}_{1,6}\right)$, komunikasi dapat menciptakan rasa saling memahami antara karyawan dengan pihak manajemen. Indikator ini dapat diukur melalui kesempatan karyawan untuk memberikan kritik dan saran atasan maupun rekan kerja.

Motivasi adalah dorongan atau semangat di dalam diri seseorang untuk mencapai tujuan yang diharapkan. Variabel motivasi diukur dengan indikator sebagai berikut: 1) Tanggung jawab $\left(\mathrm{X}_{2.1}\right)$, tanggung jawab merupakan sikap yang menunjukan bahwa seseorang memiliki sifat kepedulian, kejujuran dan ketelitian yang tinggi. Indikator ini dapat diukur melalui sikap karyawan dalam melaksanakan tugas yang diberikan. 2) Sikap atasan $\left(\mathrm{X}_{2.2}\right)$, sikap atasan merupakan tingkah laku yang diberikan atasan terhadap karyawan. Indikator ini dapat diukur melalui persepsi karyawan mengenai sikap atasan kepada karyawan. 3) Kesempatan berkarir $\left(\mathrm{X}_{2.3}\right)$, indikator ini diukur melalui kesempatan karyawan untuk meningkatkan karirnya kejenjang yang lebih tinggi, karyawan diberikan kesempatan untuk promosi jabatan. 4) Gaji dan insentif $\left(\mathrm{X}_{2.4}\right)$, indikator ini diukur melalui persepsi karyawan mengenai gaji dan insentif yang diberikan.

Lingkungan kerja adalah segala sesuatu yang ada disekitar karyawan yang dapat mempengaruhi kinerja karyawan dalam melaksanakan pekerjaannya sehingga memperoleh hasil yang maksimal. Indikator lingkungan kerja adalah 1) Penerangan atau cahaya di tempat kerja $\left(\mathrm{X}_{3.1}\right)$, penerangan dan cahaya sangat penting bagi karyawan untuk meningkatkan keselamatan dalam bekerja. Penerangan yang baik adalah penerangan yang cukup, tidak terlalu gelap dan tidak terlalu terang. Indikator ini diukur melalui persepsi karyawan mengenai penerangan 
di tempatnya bekerja. 2) Keadaan udara di tempat kerja $\left(\mathrm{X}_{3.2}\right)$, Keadaan udara di tempat kerja harus berada pada tingkat yang optimal. Hal ini bisa ditingkatkan dengan cara menerapkan sistem ventilasi yang baik atau dengan memasang air conditioner. Indikator ini dapat diukur melalui suhu udara tempat karyawan bekerja. 3) Fasilitas kerja $\left(\mathrm{X}_{3.3}\right)$, Fasilitas kerja adalah sesuatu yang terdapat dalam perusahaan yang dapat dinikmati dan digunakan oleh karyawan untuk kelancaran pekerjaannya. Indikator ini dapat diukur melalui tersedianya fasilitas yang dapat digunakan karyawan. 4) Hubungan dengan rekan kerja $\left(\mathrm{X}_{3.4}\right)$, indikator ini diukur melalui hubungan karyawan dengan rekan kerjanya. 5) Keamanan $\left(X_{3.5}\right)$, lingkungan kerja yang baik adalah lingkungan yang aman dari kejahatan, radiasi, bencana, dan hal lain yang dapat membahayakan nyawa karyawan. Indikator ini diukur melalui kenyamanan dan keamanan karyawan dalam bekerja.

Model analisis yang digunakan dalam penelitian ini adalah Regresi Linier Berganda. Adapun bentuk bentuk umum persamaan regresi linier berganda sebagai berikut:

Keterangan :

$$
\hat{Y}=\alpha+\beta_{1} X_{1}+\beta_{2} X_{2}+\beta_{3} X_{3}+e .
$$

$\begin{array}{lll}\hat{\mathrm{Y}} & = & \text { Produktivitas Karyawan } \\ \alpha & = & \text { Bilangan konstanta } \\ \mathrm{X}_{1} & = & \text { Pemberdayaan } \\ \mathrm{X}_{2} & = & \text { Motivasi } \\ \mathrm{X}_{3} & = & \text { Lingkungan kerja } \\ \beta_{1}, \beta_{2}, \beta_{3} & = & \text { Koefisien regresi variabel } \mathrm{X}_{1}, \mathrm{X}_{2}, \mathrm{X}_{3} \\ e & = & \text { error }\end{array}$

\section{HASIL DAN PEMBAHASAN}

Hasil dari penelitian yang dilakukan terhadap karyawan Legong Keraton Beach Hotel diketahui bahwa karakteristik responden meliputi jenis kelamin, usia, pendidikan dan masa kerja. Jumlah responden yang digunakan dalam penelitian ini yaitu 41 responden, dapat dilihat pada Tabel 3.

Berdasarkan Tabel 3. dapat dijelaskan bahwa karakteristik responden berdasarkan jenis kelamin, karyawan Legong Keraton Beach Hotel dominan berjenis kelamin laki-laki sebanyak 26 orang dengan persentase 63,41 persen dari total jumlah responden. Jumlah karyawan perempuan sebanyak 15 orang dengan persentase 36,59 persen dari total jumlah responden. Faktor jenis kelamin perlu mendapatkan perhatian karena berkaitan dengan kemampuan karyawan dalam menjalankan dan menyelesaikan pekerjaan dengan cepat dan tepat sehingga mencapai produktivitas kerja yang tinggi.

Karakteristik berdasarkan usia menunjukan bahwa, responden di Legong Keraton Beach Hotel sebagian besar berusia antara 30-39 tahun sebanyak 18 orang dengan persentase 43,91 persen dari jumlah responden.

Karyawan yang berusia antara 20-29 tahun sebanyak 15 orang dengan persentase 36,59 persen, sedangkan usia antara 40-49 dan 50-59 masing-masing berjumlah 4 orang dengan persentase 9,75 persen. Faktor usia dapat menunjang kegiatan perusahaan dalam menghasilkan jasa yang berkualitas, karena dengan usia 
produktif, karyawan akan melakukan pekerjaannya lebih baik dan rajin dalam pencapaian produktivitas kerja karyawan

Tabel 3.

Deskripsi Karakteristik Responden

\begin{tabular}{|c|c|c|c|c|}
\hline No & Karakteristik & Klasifikasi & $\begin{array}{l}\text { Jumlah } \\
\text { (orang) }\end{array}$ & $\begin{array}{l}\text { Persentase } \\
\text { (\%) }\end{array}$ \\
\hline \multirow[t]{3}{*}{1.} & Jenis Kelamin & Laki-laki & 26 & 63,41 \\
\hline & & Perempuan & 15 & 36,59 \\
\hline & Jumlah & & 41 & 100 \\
\hline \multirow[t]{5}{*}{2.} & Usia & $20-29$ & 15 & 36,59 \\
\hline & & $30-39$ & 18 & 43,91 \\
\hline & & $40-49$ & 4 & 9,75 \\
\hline & & $50-59$ & 4 & 9,75 \\
\hline & Jumlah & & 41 & 100 \\
\hline \multirow[t]{4}{*}{3.} & Pendidikan & SMA/Sederajat & 15 & 36,59 \\
\hline & & Diploma & 20 & 48,78 \\
\hline & & Sarjana & 6 & 14,63 \\
\hline & Jumlah & & 41 & 100 \\
\hline \multirow[t]{4}{*}{4.} & Masa Kerja & $<1$ tahun & 5 & 12,20 \\
\hline & & $1-2$ tahun & 6 & 14,63 \\
\hline & & $>3$ tahun & 30 & 73,17 \\
\hline & Jumlah & & 41 & 100 \\
\hline
\end{tabular}

Sumber: Legong Keraton Beach Hotel, 2018

Karakteristik berdasarkan pendidikan menunjukan bahwa karyawan di Legong Keraton Beach Hotel dominan memiliki jenjang pendidikan terakhir Diploma sebanyak 20 orang dengan persentase 48,78 persen dari jumlah responden sebanyak 41 orang. Karyawan dengan pendidikan terakhir SMA/Sederajat berjumlah 15 orang dengan persentase 36,59 persen, sedangkan karyawan yang memiliki pendidikan terakhir sarjana hanya 6 orang dengan persentase 14,63 persen. Pendidikan responden merupakan salah satu penentu kualitas SDM.

Karakteristik berdasarkan masa kerja menunjukan bahwa karyawan Legong Keraton Beach Hotel dominan memiliki masa kerja lebih dari 3 tahun sebanyak 30 orang dengan persentase 73,17 persen, sedangkan karyawan yang memiliki masa kerja kurang dari 1 tahun sebanyak 5 orang dengan persentase 12.20 persen dan yang memiliki masa kerja antara 1-2 tahun sebanyak 6 orang dengan persentase 14,63 persen. Masa kerja merupakan periode waktu yang dilalui karyawan dalam bekerja.

Pemberdayaan adalah hubungan antara kelompok atau individu dengan manajemen organisasi untuk membangun kepercayaan dalam memberikan tanggung jawab, wewenang untuk melaksanakan pekerjaan dan mengambil keputusan. Hasil kuesioner yang diisi oleh karyawan Legong Keraton Beach Hotel menunjukkan rata-rata keseluruhan indikator sebesar 4,17 yang berarti nilai tersebut berada di antara 3,41-4,20 dengan kriteria baik, ini menunjukkan bahwa pemberdayaan pada Legong Keraton Beach Hotel dalam kondisi yang baik.

Pernyataan kedua yaitu "Saya selalu membangun hubungan yang baik dengan rekan kerja", memiliki skor nilai rata-rata tertinggi sebesar 4,46, nilai ini memiliki 
arti bahwa karyawan Legong Keraton Beach Hotel ini memiliki hubungan yang baik antar sesama rekan kerja

Skor terendah terdapat pada pernyataan kelima "Saya diberikan wewenang untuk membuat keputusan yang tepat dalam melaksanakan pekerjaan". Memiliki nilai 3,73. Nilai ini memiliki arti bahwa karyawan Legong Keraton Beach Hotel tidak sepenuhnya memiliki wewenang untuk membuat keputusan dalam bekerja. Perusahaan sebaiknya memberikan kesempatan karyawan untuk membuat keputusan yang menyangkut pekerjaan yang diemban.

Motivasi adalah dorongan atau semangat di dalam diri seseorang untuk mencapai tujuan yang diharapkan. Hasil kuesioner yang diisi oleh karyawan Legong Keraton Beach Hotel menunjukkan rata-rata keseluruhan indikator sebesar 3,85 yang berarti nilai tersebut berada di antara 3,41-4,20 dengan kriteria tinggi, ini menunjukkan bahwa motivasi di Legong Keraton Beach Hotel dalam kondisi yang tinggi, dapat diketahui pernyataan pertama yaitu "Saya memiliki tanggung jawab yang tinggi dalam bekerja", memiliki skor nilai rata-rata tertinggi sebesar 4,42, nilai ini memiliki arti bahwa karyawan Legong Keraton Beach Hotel ini mempunyai tanggung jawab dalam melakukan pekerjaannya

Skor terendah terdapat pada pernyataan kelima "Gaji yang diberikan kepada saya sesuai dengan beban kerja saya",memiliki nilai 3,56. Nilai ini memiliki arti bahwa karyawan Legong Keraton Beach Hotel dalam bekerja masih ada yang belum puas dan menganggap gaji yang diberikan belum sesuai dengan beban kerja. Untuk mengatasi permasalahan tersebut karyawan juga seharusnya meningkatkan kemampuan yang dimiliki supaya dapat memberikan kontribusi lebih ke perusahaan yang nantinya diberikan imbalan oleh perusahaan.

Hasil kuesioner yang diisi oleh karyawan Legong Keraton Beach Hotel menunjukkan rata-rata keseluruhan indikator sebesar 3,91 yang berarti nilai tersebut berada di antara 3,41-4,20 dengan kriteria baik, ini menunjukkan bahwa lingkungan kerja di Legong Keraton Beach Hotel dalam kondisi yang baik.

Pernyataan pertama yaitu "penerangan di tempat saya bekerja sudah baik", memiliki skor nilai rata-rata tertinggi sebesar 4,15, nilai ini memiliki arti bahwa penerangan di Legong Keraton Beach Hotel sudah sesuai dan skor terendah terdapat pada pernyataan keenam "Tempat istirahat yang disediakan di perusahaan saya dalam kondisi baik dan bersih" memiliki nilai 3,32. Nilai ini memiliki arti bahwa kebersihan tempat istirahat di Legong Keraton Beach Hotel belum baik dan perlu ditingkatkan lagi. Perusahaan sebaiknya mengontrol karyawan yang memiliki tugas untuk membersihkan tempat istirahat dan karyawan lain yang menggunakan juga harus ikut menjaga kebersihan tempat istirahat supaya dapat beristirahat dengan nyaman.

Produktivitas kerja karyawan adalah kemampuan untuk meningkatkan hasil kerja dan mencapai tugas-tugas tertentu sesuai dengan standar yang ditetapkan. Hasil kuesioner yang diisi oleh karyawan Legong Keraton Beach Hotel menunjukkan rata-rata keseluruhan indikator sebesar 4,23 yang berarti nilai tersebut berada di antara 4,21-5,00 dengan kriteria sangat tinggi, ini menunjukkan bahwa produktivitas kerja karyawan di Legong Keraton Beach Hotel dalam kondisi sangat tinggi, dapat diketahui pernyataan kelima yaitu "saya selalu bersemangat dalam memenuhi target", memiliki skor nilai rata-rata tertinggi sebesar 4,56, nilai 
ini memiliki arti bahwa karyawan di Legong Keraton Beach Hotel selalu bersemangat dalam mencapai target yang telah ditetapkan

Skor terendah terdapat pada pernyataan kedua "saya memiliki kemampuan bekerja secara profesional" memiliki nilai 4,00. Nilai ini memiliki arti bahwa karyawan di Legong Keraton Beach Hotel belum bekerja sesuai dengan kemampuan yang dimiliki. Perusahaan

Tabel 6.

Hasil Uji Normalitas

\begin{tabular}{lc}
\hline & Unstandardized Residual \\
\hline $\mathrm{N}$ & 41 \\
Kolmogorov-Smirnov Z & 1,038 \\
Asymp. Sig. (2-tailed) & 0,231 \\
\hline Sumber: Data diolah, 2018 &
\end{tabular}

Tabel 6. menunjukan bahwa Asymp. Sig. (2-tailed) memiliki nilai 0,231. Nilai ini menunjukan bahwa Asymp. Sig. (2-tailed) lebih besar >0,05 yang artinya data berdistribusi normal.

Tabel 7.

Hasil Uji Multikolinieritas

\begin{tabular}{ccc}
\hline Model & Colinierity Statistic & \\
& Tolerance & VIF \\
\hline Pemberdayaan $\left(\mathrm{X}_{1}\right)$ & 0,703 & 1,423 \\
Motivasi $\left(\mathrm{X}_{2}\right)$ & 0,604 & 1,656 \\
Lingkungan Kerja $\left(\mathrm{X}_{3}\right)$ & 0,590 & 1,696 \\
\hline
\end{tabular}

Sumber: Data diolah, 2018

Tabel 7. menunjukan bahwa koefisien Tolerance untuk variabel bebas menunjukan nilai Tolerance $>0,10$ atau mempunyai nilai $\mathrm{VIF}<10$, artinya tidak terdapat multikolinieritas dalam model regresi.

Uji heteroskedastisitas dilakukan dengan menggunakan Uji Glejser dengan ketentuan jika nilai signifikan di atas 0,05 maka memiliki arti tidak terjadi heteroskedastisitas. Model uji heteroskedastisitas ditunjukan pada Tabel 8 .

Tabel 8.

Hasil Uji Heteroskedastisitas

\begin{tabular}{ccc}
\hline Model & Sig. & Keterangan \\
\hline Pemberdayaan $\left(\mathrm{X}_{1}\right)$ & 0,200 & Bebas Heteroskedastisitas \\
Motivasi $\left(\mathrm{X}_{2}\right)$ & 0,689 & Bebas Heteroskedastisitas \\
Lingkungan kerja $\left(\mathrm{X}_{3}\right)$ & 0,310 & Bebas Heteroskedastisitas \\
\hline
\end{tabular}

Sumber: Data diolah, 2018

Tabel 8. menunjukan bahwa nilai signifikansi dari ketiga variabel bebas yaitu variabel pemberdayaan dengan signifikansi 0,200, variabel motivasi dengan signifikansi 0,689 dan variabel lingkungan kerja dengan signifikansi 0,310. Ketiga variabel tersebut memiliki nilai signifikansi diatas 0,05 artinya model regresi bebas dari gejala heteroskedastisitas. 
Nilai sig. annova $<\alpha=0,05$ maka model ini dikatakan layak atau ada pengaruh yang signifikan antara variabel bebas terhadap variabel terikat. Hasil yang diperoleh menunjukan bahwa nilai signifikansi $\mathrm{F}$ adalah sebesar 0,000 lebih kecil dari $0,05(\mathrm{~F}<\alpha)$ yang berarti variabel bebas yaitu pemberdayaan $\left(\mathrm{X}_{1}\right)$, motivasi $\left(\mathrm{X}_{2}\right)$, dan lingkungan kerja $\left(\mathrm{X}_{3}\right)$ berpengaruh signifikan terhadap produktivitas kerja karyawan $(\mathrm{Y})$, maka model regresi linier berganda layak digunakan sebagai alat analisis.

Hasil uji koefisien determinasi $\left(\mathrm{R}^{2}\right)$ menunjukan bahwa besarnya nilai $\mathrm{R}$ square adalah sebesar 0,489 yang artinya 48,9 persen variasi produktivitas kerja karyawan dipengaruhi oleh pemberdayaan, motivasi, dan lingkungan kerja, sedangkan sisanya sebesar 51,1 persen dipengaruhi oleh faktor lain yang tidak dimasukkan ke dalam model penelitian.

Berdasarkan hasil uji regresi linier berganda, diketahui bahwa variabel pemberdayaan memiliki nilai koefisien beta positif sebesar 0,819 dengan nilai signifikansi sebesar 0,000. Nilai koefisien beta $>0$ dan nilai signifikansi $<0,05$ menunjukan bahwa pemberdayaan berpengaruh positif dan signifikan terhadap produktivitas kerja karyawan.

Berdasarkan hasil uji regresi linier berganda, diketahui bahwa variabel motivasi memiliki nilai koefisien beta positif sebesar 0,537 dengan nilai signifikansi sebesar 0,003. Nilai koefisien beta $>0$ dan nilai signifikansi $<0,05$ menunjukan bahwa motivasi berpengaruh positif dan signifikan terhadap produktivitas kerja karyawan.

Berdasarkan hasil uji regresi linier berganda, diketahui bahwa variabel lingkungan kerja memiliki nilai koefisien beta positif sebesar 0,329 dengan nilai signifikansi sebesar 0,022. Nilai koefisien beta $>0$ dan nilai signifikansi $<0,05$ menunjukan bahwa lingkungan kerja berpengaruh positif dan signifikan terhadap produktivitas kerja karyawan.

Hasil penelitian menunjukkan bahwa pemberdayaan berpengaruh positif dan signifikan terhadap produktivitas kerja karyawan. Pemberdayaan di Legong Keraton Beach Hotel sudah baik, karena karyawan Legong Keraton Beach Hotel sudah terlibat dalam menyelesaikan pekerjaan, membangun hubungan yang baik dengan rekan kerja maupun manajemen, memiliki wewenang untuk membuat keputusan, berkomunikasi yang baik dan memiliki kesempatan untuk memberikan masukan.

Hasil penelitian ini menunjukkan adanya hubungan antara pemberdayaan dengan produktivitas kerja karyawan. Hal ini sejalan dengan hasil penelitian yang dilakukan oleh Chang dan Liu (2007) mengatakan bahwa pemberdayaan merupakan faktor penting dalam meningkatkan produktivitas. Chehrazi dan Shafizadeh (2016) menyatakan bahwa terdapat hubungan yang erat antara pemberdayaan karyawan dengan kepuasan kerja, sehingga dapat meningkatkan produktivitas.

Menurut Hanaysha (2016) pemberdayaan karyawan telah secara luas diakui sebagai kontributor kunci keberhasilan organisasi, dan banyak yang meneliti hubungan langsung antara tingkat pemberdayaan karyawan dan produktivitas kerja. Pemberdayaan memberikan pengaruh yang kuat terhadap produktivitas (Arifin et al., 2014). Pemberdayaan memiliki pengaruh positif dan signifikan terhadap 
produktivitas karyawan (Prabawa \& Supartha, 2018). Hipotesis ini berarti bahwa semakin baik pemberdayaan terhadap karyawan maka semakin tinggi pula produktivitas kerja karyawan.

Hasil penelitian menunjukkan bahwa motivasi berpengaruh positif dan signifikan terhadap produktivitas kerja karyawan. Motivasi di Legong Keraton Beach Hotel tinggi, karena karyawan Legong Keraton Beach Hotel sudah memiliki rasa tanggung jawab, sudah merasa diperlakukan adil oleh atasan, diberikan kesempatan meraih jenjang karir, gaji yang diberikan sudah sesuai, dan diberikan insentif/bonus.

Hasil penelitian ini menunjukkan adanya hubungan antara motivasi dengan produktivitas kerja karyawan. Hal ini sejalan dengan hasil penelitian yang dilakukan oleh Hamali (2013) menunjukan bahwa motivasi berpengaruh positif terhadap produktivitas karyawan. Motivasi mempunyai pengaruh positif dan signifikan terhadap produktivitas kerja karyawan. Pengaruh yang positif ini menunjukkan bahwa semakin baik persepsi responden mengenai dorongan motivasi pegawai telah berhasil meningkatkan produktivitas kerja (Purwanto \& Wulandari, 2016).

Omollo (2015) juga menilai bahwa motivasi berpengaruh positif terhadap produktivitas kerja karyawan jika imbalan yang diterima sesuai dengan apa yang menjadi beban pekerjaan karyawan itu. Maduka dan Okafor (2014) mengatakan bahwa motivasi menjadi hal yang sangat berpengaruh dan penting dalam meningkatkan produktivias dari organisasi. Nuraini et al. (2015) juga mengatakan bahwa motivasi berpengaruh secara parsial terhadap produktivitas kerja karyawan. Hipotesis ini berarti bahwa semakin tinggi motivasi karyawan maka semakin tinggi pula produktivitas kerja karyawan.

Hasil penelitian menunjukkan bahwa lingkungan kerja berpengaruh positif dan signifikan terhadap produktivitas kerja karyawan. Lingkungan kerja di Legong Keraton Beach Hotel sudah baik, karena karyawan Legong Keraton Beach Hotel sudah merasa penerangan, suhu udara, sirkulasi udara, peralatan kerja fasilitas yang disediakan,tempat istirahat sudah baik dan nyaman, karyawan juga menjalin hubungan yang baik dengan karyawan lain, lingkungan kerja juga aman.

Hasil penelitian ini menunjukkan adanya hubungan antara lingkungan kerja dengan produktivitas kerja karyawan. Hal ini sejalan dengan hasil penelitian yang dilakukan oleh Nuraini et al. (2015) menyimpulkan bahwa motivasi dan lingkungan kerja berpengaruh positif terhadap produktivitas karyawan. Lingkungan kerja berpengaruh positif terhadap produktivitas kerja karyawan bagian produksi minyak kelapa sawit PT. Mitra (Swandono, 2016). Penelitian yang dilakukan oleh Taiwo (2010) menyatakan bahwa lingkungan kerja dapat meningkatkan produktivitas kerja karyawan karena lingkungan kerja yang kondusif.

Penelitian yang dilakukan oleh Senata et al. (2014) menyatakan bahwa Lingkungan kerja berpengaruh positif terhadap produktivitas kerja karyawan. Menurut Ajala (2012) Lingkungan tempat kerja yang kondusif yang membantu kinerja kerja secara otomatis meningkatkan produktivitas Hipotesis ini berarti bahwa semakin baik lingkungan kerja maka semakin tinggi pula produktivitas kerja karyawan. 
Hasil dari penelitian ini memiliki implikasi teoritis dan praktis, secara teoritis penelitian ini menunjukan pemberdayaan, motivasi dan lingkugan kerja berpengaruh positif dan signifikan terhadap prouktivitas kerja karyawan. Hasil penelitian ini memberikan dukungan empiris dan dapat memperkuat penelitianpenelitian sebelumnya.

Secara praktis penelitian ini diharapkan dapat memberikan manfaat bagi perusahaan dan karyawan Legong Keraton Beach Hotel, dimana perusahaan harus memperhatikan pemberdayaan yang diberikan seperti memberikan wewenang kepada karyawan dalam membuat keputusan kepada karyawan agar dalam melakukan pekerjaan karyawan dapat terlibat langsung dan mempunyai rasa tanggung jawab sehingga produktivitas kerja karyawan dapat meningkat.

Pihak perusahaan juga harus dapat memberikan motivasi terhadap karyawan dalam bekerja. Perusahaan harus mendekati karyawan dan selalu memotivasi karyawan agar semangat dalam bekerja dan memberikan gaji yang sesuai dengan pekerjaan karyawan yang nantinya akan berpengaruh terhadap produktivitas kerja karyawan.

Selain itu pihak perusahaan juga harus memperhatikan lingkungan kerja. Apabila lingkungan kerja sudah baik, nyaman dan bersih, karyawan akan merasa nyaman saat bekerja dan dapat menyelesaikan pekerjaan dengan cepat dan tepat, sehingga dapat meningkatkan produktivitas kerja karyawan.

\section{SIMPULAN}

Pemberdayaan memiliki pengaruh positif dan signifikan terhadap produktivitas kerja karyawan. Hal ini menunjukan bahwa semakin baik pemberdayaan yang diberikan perusahaan terhadap karyawan maka semakin tinggi produktivitas kerja karyawan dalam perusahaan.

Motivasi memiliki pengaruh positif dan signifikan terhadap produktivitas kerja karyawan. Hal ini menunjukan bahwa semakin tinggi motivasi yang dimiliki karyawan terhadap perusahaan maka produktivitas kerja karyawan dalam perusahaan akan meningkat. Lingkungan kerja memiliki pengaruh positif dan siginifikan terhadap produktivitas kerja karyawan. Hal ini menunjukan bahwa semakin baik lingkungan kerja dalam perusahaan maka produktivitas kerja karyawan dalam perusahaan semakin tinggi.

Perusahaan harus mempertahankan pemberdayaan yang sudah dilakukan sebelumnya dan meningkatkan pemberdayaan dalam hal kredibilitas terhadap karyawan seperti melibatkan karyawan dalam proses perencanaan dan pembuatan keputusan. Dengan demikian, karyawan akan merasa lebih percaya diri dalam membuat suatu keputusan dan memiliki rasa tanggung jawab sehingga dapat meningkatkan produktivitas kerja.

Manajemen perusahaan sebaiknya memperhatikan dan meningkatkan bagaimana cara memberikan motivasi kepada karyawan dalam melaksanakan pekerjaannya. Salah satu cara yang dapat dilakukan yaitu dengan memberikan gaji yang sesuai dengan beban kerja karyawan agar karyawan termotivasi untuk bekerja lebih baik dan rajin. Hal ini akan meningkatkan produktivitas kerja karyawan yang nantinya berguna untuk kemajuan perusahaan. 
Perusahaan harus mampu mempertahankan dan meningkatkan lingkungan kerja yang nyaman, bersih, dan kondusif untuk memberikan kenyamanan dan keamanan kepada karyawan dalam melakukan pekerjaan. Selain itu perusahaan harus memperhatikan dan menyediakan tempat istirahat yang bersih sehingga karyawan dapat beristirahat dengan nyaman dan ketika bekerja kembali karyawan akan merasa senang, semangat yang nantinya dapat meningkatkan produktivitas kerja karyawan.

\section{REFERENSI}

Ahmed, K., Sultana, A., Irum, S., \& Mehmood, N. (2012). Impact Of Training On Employee Performance: A Study Of Telecommunication Sector In Pakistan. Interdisciplinary Journal of Contemporary Research in Business, 4(6), 646661. https://doi.org/10.18052/www.scipress.com/ILSHS.17.60

Ahyari, A. (2011). Manajemen Produksi Perencanaan Produksi. Yogyakarta: BPFE.

Ajala, E. M. (2012). Calibration transfer between different analytical methods. The African Symposium: An Online Journal of the African Educational Research Network, 12(1), 141-149. Retrieved from https://pdfs.semanticscholar.org/ 24e5/7a6b52d6e8f5c61f7349d0d7a14d7d6f4018.pdf

Ardana, I. K., Mujiati, N. W., \& Utama, I. W. M. (2014). Manajemen Sumber Daya Manusia (1st ed.). Yogyakarta: Graha Ilmu.

Arifin, A., Hamid, D., \& M, S. H. (2014). Pengaruh Pemberdayaan dan Motivasi terhadap Produktivitas Kerja Karyawan (Study Pada Karyawan CV. Catur Perkasa Manunggal). Jurnal Administrasi Bisnis (JAB), 8(2), 125-132. Retrieved from http://download.portalgaruda.org/article.php?article=189 799\&val=6468\&title=Pengaruh Pemberdayaan Dan Motivasi Terhadap Kinerja Karyawan (Studi pada Karyawan CV. Catur Perkasa Manunggal)

Asgarsani, H., Duostdar, O., \& Rostami, A. (2013). Interdisciplinary Journal Of Contemporary Research In Business Empowerment And Its Impact On The Organization Productivity. International Journal Of Contemporary Research In Business, 4(11), 738-744. Retrieved from https://pdfs.semanticscholar.org/18fe/b47ae856137 85e2ea9cad8de25cb62bd6a22.pdf

Bachtiar, D. (2012). Pengaruh Motivasi Dan Lingkungan Kerja Terhadap Kinerja Karyawan. Management Analysis Journal, 1(1), 212-218. https://doi.org/10.1111/1467-6281.00054

Chang, L., \& Liu, C. (2007). Employee empowerment, innovative behavior and job productivity of public health nurses: a cross-sectional questionnaire survey. International Journal of Nursing Studies, 45(10), 1442-1448. Retrieved from https://www.ncbi.nlm.nih.gov/pubmed/18295217

Chehrazi, K. A., \& Shafizadeh, R. (2016). The Relationship of Empowerment and 
Job Satisfaction with Productivity of Employees of Education System in Ahwaz. International Journal of Learning and Development, 6(1), 11-24. https://doi.org/https://doi.org/10.5296/ijld.v6i1.8928

Chen, K. P. (2011). A Study On The Impact Of Empowerment On Employee Perfomance In The Automotive Industry In Malaysia. Open University Malaysia. Retrieved from http://library.oum.edu.my/repository/671/1/study _kok.pdf

Elnaga, A. A., \& Imran, A. (2014). The Impact of Employee Empowerment on Job Satisfaction Theoretical Study. American Journal of Research Communication , 2(1), 13. https://doi.org/10.1108/17506141111163390

Ferreira, A., \& Plessis, T. Du. (2009). Effect of Online Social Networking on Employee Productivity. Peer Reviewed Article, 11(1), 1-16. Retrieved from https://sajim.co.za/index.php/sajim/article/download/397/384

Hamali, A. Y. (2013). Pengaruh MotivasiTerhadap ProduktivitasKerja: Studi Kasus Pada PT X Bandung. The Winners, 14(2), 77-86. Retrieved from http://journal.binus.ac.id/index.php/winners/article/download/647/624

Hanaysha, J. (2016). Testing the Effects of Employee Empowerment, Teamwork, and Employee Training on Employee Productivity in Higher Education Sector. International Journal of Learning \& Development, 6(1), 164-178. https://doi.org/10.5296/ijld.v6i1.9200

Huzain, S. (2015). Peran Pimpinan Dalam Meningkatkan Produktivitas Kerja Karyawan Pada Pt . Graha Mandala Sakti. EJournal Ilmu Pemerintahan, 3(1), 479-493. Retrieved from http://ejournal.ip.fisip-unmul.ac.id/site/wpcontent/uploads/2015/03/Jurnal (03-19-15-10-21-20).pdf

Itumbiri, M. P. (2013). Perceived Factors That Affect Employees' Productivity Within Redeemed Integrated Development Agency a Research Project Submitted in Partial Fulfillment of the Requirement for the Award of the Degree of Master of Business Administration, School of Business. School of Business Unversity of Nairobi.

Jacquiline, F. N. (2014). Employee Empowerment And Job Satisfaction. Researchjournali's Journal of Human Resource, 2(2), 1-12. Retrieved from https://123doc.org/document/2796332-factors-affecting-the-fluctuation-oflabour-productivity-in-the-construction-projects.htm

Kien, B. T. (2012). Factors affecting the fluctuations of labour productivity in the construction projects. University of Economic HO CHI MINH CITY.

Lea, A. S., \& Wibawa, I. M. A. (2014). Pengaruh Kompensasi dan Lingukan Kerja Pada Loyalitas Karyawan Berdasarkan Jenis Kelamin. E-Jurnal Manajemen Unud, 3(10), 3078-3095. Retrieved from https://ojs.unud.ac.id/index.php/ Manajemen/article/view/9426/7550

Maduka, C. E., \& Okafor, D. O. (2014). Effect of Motivation on Employee 
Productivity: A Study of Manufacturing Companies in Nnewi. International Journal of Managerial Studies and Research (IJMSR), 2(7), 137-147. Retrieved from https://www.arcjournals.org/pdfs/ijmsr/v2-i7/14.pdf

Maslichah, N. I., \& Hidayat, K. (2017). Pengaruh Work-Life Balance dan Lingkungan Kerja Terhadap Kepuasan Kerja Karyawan ( Studi pada Perawat RS Lavalette Malang Tahun 2016 ). Jurnal Administrasi Bisnis, 49(1), 60-68. Retrieved from http://administrasibisnis.studentjournal.ub.ac.id/index.php/ jab/article/download/1895/2278

Meyerson, G., \& Dewettinck, B. (2012). Effect of empowerment on employees performance. Advanced Research in Economic and Management Sciences, 2(7), 40-46. https://doi.org/10.1017/CBO9781107415324.004

Nuraini, Indarti, S., \& Marzolina. (2015). Pengaruh Lingkungan Kerja dan Motivasi terhadap Produktivitas Kerja Karyawan pada PT. Perkebunan Nusantara V Cabang Kebun Inti Kecamatan Tapung Kabupaten Kampar. JOM Fekon, 2(1), 1-15. Retrieved from https://media.neliti.com/media/publications/33806-IDpengaruh-lingkungan-kerja-dan-motivasi-terhadap-produktivitas-kerjakaryawan-pad.pdf

Omollo, P. A. (2015). Effect of motivation on employee performance of commercial banks in Kenya: A case study of Kenya Commercial Bank in Migori County. International Journal of Human Resource Studies, 5(2), 87103. https://doi.org/10.1108/02652320210451223

Prabawa, A. I. M., \& Supartha, I. W. G. (2018). Meningkatkan Produktivitas Karyawan Melalui Pemberdayaan, Kerja Sama Tim dan Pelatihan di Perusahaan Jasa. E-Jurnal Manajemen Unud, 7(1), 497-524. https://doi.org/https://doi.org/10.24843/EJMUNUD.2018.v7.i01.p19

Purwanto, A. B., \& Wulandari, O. (2016). Pengaruh Motivasi, Kompensasi dan Lingkungan Kerja Terhadap Produktivitas Kerja Karyawan. Buletin Bisnis \& Manajemen, 2(1), 9-26. Retrieved from http://journal.stie-yppi.ac.id/index. $\mathrm{php} / \mathrm{BBM} /$ article/view/2/2

Salistera, S. Y., \& Kusumastuti, R. (2013). Pengaruh Lingkungan Kerja terhadap Produktivitas Kerja Karyawan pada Production Plant PT Indocement Tunggal Prakarsa TBK Citeurep. Fakultas Ilmu Sosial Dan Ilmu Politik, Universitas Indonesia, 1(1), 1-18. Retrieved from http://lib.ui.ac.id/naskahringkas/201509/S46515-sinta yulis salistera

Senata, I. W., Nuridja, I. M., \& Suwena, K. R. (2014). Pengaruh Lingkungan Kerja Terhadap Produktivitas Kerja Karyawan UD. Kembang Sari Kabupaten Bandung Tahun 2012. Jurnal Pendidikan Ekonomi Undiksha, 4(1), 1-10. Retrieved from https://ejournal.undiksha.ac.id/index.php/JJPE/article/ download/2021/1762

Subagyo, A. (2014). Pengaruh Lingkungan Kerja Dan Self Efficacy terhadap Komitmen Organisasional Dosen Politeknik Negeri Semarang. ORBITH, 
10(1), 74-81. Retrieved from http://jurnal.polines.ac.id/index.php/orbith/ article/view/365/320

Sutrisno, H. E. (2009). Manajemen Sumber Daya Manusia (1st ed.). Jakarta: Kencana.

Swandono, S. (2016). Pengaruh Lingkungan Kerja Terhadap Produktivitas Kerja Karyawan (Bagian Produksi Minyak Kelapa Sawit Pt.Mitra Unggul Pusaka Segati Pelalawan Riau). Jom Fisip, 3(2), 1-13. Retrieved from https://media.neliti.com/media/publications/33206-ID-pengaruh-lingkungankerja-terhadap-produktivitas-kerja-karyawan-bagian-produksi.pdf

Taiwo, A. S. (2010). The influence of work environment on workers productivity: A case of selected oil and gas industry in Lagos, Nigeria. African Journal of Business Management, 4(3), 299-307. https://doi.org/ISSN 1993-8233 